\title{
LANGUAGE STRATEGIES FOR THE ADAPTATION OF WESTERN BRAND NAMES IN TAIWAN
}

Keywords: brand names, Chinese brand names, Western brand names in Taiwan, adaptation of foreign brands, language strategies of naming

\section{INTRODUCTION}

The paper deals with some language strategies in the domain of the adaptation of foreign brand names (trade names) in Taiwan (ROC) in the context of Chinese language, society and culture. It also presents the results of the author's investigation into 50 Chinese/Taiwanese adaptations of brands of foreign food products.

In the Chinese naming culture, proper names are predominantly semantically transparent and most members of Chinese society still believe that names can influence the fate of the objects named. It is evident, that brand names play a crucial role in the marketing of products and in their acceptance by the consumers, and ultimately their purchase decisions. Good and pleasing brand names contribute to the success of products, while improper and ugly names may contribute to their failure. In a time of globalization, many foreign products and brand names occur in Chinese-speaking countries, such as the PRC and Taiwan, probably the largest consumer markets in international business. Consumers' behavior and language are usually among the major barriers to the international market, so it is important to know the linguistic and social content of Chinese names and typical language strategies for the adaptation of Western brand names.

\section{LINGUISTIC COMPONENT OF GLOBAL BRANDING}

Global branding is complicated by the diversity of languages, economics, and legal and cultural factors. The function of brands is to make the branded products recognizable and distinguishable for both promotion and selling. There are 
three-component criteria for the successful development of brand names (Chan \& Huang, 1997, p. 228; 2001, pp. 105-108): the marketing, the legal, and the linguistic component. Each of these components makes its own specific requirements in creating a new brand. However, the linguistic content is usually considered the essence of branding, because it directly affects the function of brand names. The linguistic component deals with three types of requirements for brand names. These are as below.

(1) Phonetic requirements: brand names need to be easy to pronounce; pleasing when read or heard; preferably without consonant clusters, and pronounceable in only one way and in all languages.

(2) Morphological requirements: brand names need to be short and simple, preferably simple words or compound words of a clear structure.

(3) Semantic requirements: brand names need to be positive, not offensive, obscene, or negative; they should be modern and contemporary, always timely; they need to be understandable and memorable, as contemporary things are more familiar to people than out-of-date ones.

The Chinese language is very different from Indo-European languages in language typology, and it is considered that the linguistic component (of the three-component criteria for the development of brand names) is more essential in Chinese branding than branding in other languages (cf. Chan \& Huang, 2001, p. 105).

\section{CHINESE LANGUAGE FEATURES IN THE CONTEXT OF THE ADAPTATION OF FOREIGN BRAND NAMES}

Chinese differs from Indo-European languages in a great variety of ways. From the point of view of branding and adaptation of foreign names, it has the following specific features, enumerated below (cf. Chan \& Huang, 1997, pp. 229-230; Chao, 1968; Kałużyńska, 2002, pp. 27-28, 88-96; 2008, pp. 33-36).

(1) Chinese is an isolating language, most of its words consist of a single morpheme, word formation in Chinese is mainly through the compounding of semantic morphemes. Bisyllabic words or words consisting of more syllables are in most cases compound words. Chinese has a logographic writing system in which the written character represents both the meaning and pronunciation of a monosyllabic word or morpheme.

(2) Chinese has a very simple syllable structure system $[\mathrm{C}] \mathrm{V}$ or $[\mathrm{C}] \mathrm{V}[\mathrm{C}](\mathrm{C}$ stands for consonant, [ ] means that the presence of consonants is optional, and $\mathrm{V}$ stands for vowel, diphthong or triphthong), and a limited number of syllables used (about 400 , specified by tones 1,227 ). Chinese does not allow any consonant clusters, foreign words with consonant clusters are very 
difficult for Chinese speakers to pronounce. Every syllable in Chinese is represented by a character in the written form. Words consisting of more than one syllable are written with as many characters as there are syllables. Each syllable can usually be considered to be a meaningful word or morpheme. In some cases, the characters are used purely for their phonetic value, i.e. they are employed for the notation of syllables/morphemes/words of identical or similar pronunciation as phonetic and graphical representation of syllables transcribed.

(3) Chinese is a tonal language, in Modern Standard Chinese (MSC) there are four distinctive tones. Tones are related with pitches, the use of different pitches contrasts meanings of words. Phonetically, high tones (T1-55, T2-35) mean a high pitch, and are more sonorous, while low tones (T3-214, T4-51) have a low pitch with less sonority. Sonority is considered an important factor by Chinese speakers for a pleasing name. European languages are mostly nontone languages, so their branding makes no tonal requirements. In the Chinese phonetic alphabet (Pinyin) different tones are written with different diacritical marks above the vowel-letter, e.g. $m \bar{a}, m a ́, m a ̆, m a ̀$.

(4) All Chinese words (proper names included) are constructed from the same source of meaningful morphemes. In MSC there are about 9,400 generally used morphemes, of which 3,500 are frequently used.

\section{CHINESE NAMING IN THE CONTEXT OF BRANDING}

In Chinese naming, proper names (onyms) are in most cases semantically transparent (a factor connected with some specific features of the Chinese language enumerated above), and it is a generally held belief that the name influences the being of the object named (cf. Kałużyńska, 2008, pp. 9-20). The relationship between the name and the reality was/is chiefly regarded as neither formal nor ideal, but as real and very important. The name is not simply considered as a symbol distinguishing one object from another, but as being inseparable from this object's fate. Chinese naming practices do not restrict the inventory of possible proper names, i.e. onyms are formed individually, mainly by a process of onymization of appellatives. Using proper names with more or less clear lexical meanings is connected with various social functions commonly attached to the meaningfulness of names. These functions of transparent names are perceived as being additional ones, other than the primary universal function of identification. Chinese names of various types and categories contain some information which falls within the content of culture, in the broad meaning of the word. They are often imbued with information on history, religion, social organization, 
mentality, values, preferences or symbols. They carry important cultural or social messages, e.g. on the system of values common to the entire society or a smaller group, on social aspirations and preferences, on the pursuit of prestige or higher status. Cultural issues include people's motivations rooted in their value system, the magic role of names, religious motivations, choices based on aesthetic values, on fashion etc.

With their onyms semantically transparent, Chinese people expect that almost all proper names (foreign names included) will have their appropriate meaning.

\section{CHINESE NAMES OF CHINESE LOCAL BRANDS}

Some researchers on Chinese local brand names (cf. Chan \& Huang, 1997, pp. 231-232; Fan, 2002, pp. 181-182; Jin, 2002, pp. 222-239; Kałużyńska, 2011, p. 237; Luo, 2001, p. 69) consider the most needed characteristics of pleasing Chinese brand names as below.

(1) Chinese brand names need to be short. It is stated, that the majority of Chinese brand names (90.5\%) are in two syllables, $6.45 \%$ are in three syllables, there are very few one-syllabled brands and those of four syllables.

(2) Tones of Chinese syllables/morphemes need to be in a proper sequence. Having considered tones T1-55 and T2-35 as high tones (H), and T3-214 and T4-51 as low tones (L), the most preferable tone structures in two-syllables are: $\mathrm{H}-\mathrm{H}$ (47.13\%), L-H (25.48\%). Phonetically, high tones mean a high pitch, and are more sonorous, while low tones have a low pitch with less sonority. Sonority is considered an important factor for a pleasing name by Chinese speakers.

(3) The most typical morphological structures of local brand names are compound names: noun-noun compounds $(51.61 \%)$ and adjective-noun compounds $(10.06 \%)$.

(4) Semantically, pleasing Chinese brand names need to be positive, not offensive. It is held that local brand names generally fall into three groups: positive $(66.03 \%)$, neutral $(33.78 \%)$, negative $(0.18 \%)$. Positive symbolic terms occur most frequently, because one of the Chinese cultural characteristics is the aspiration for symbolic implications of good wishes and fortune. Another special feature in Chinese branding is the use of names of favorite Chinese animals, like dragons, horses, cranes, pandas, swans, the phoenix, or deer $(9.35 \%)$ and plants, like plum blossom, peony, chrysanthemum $(11.39 \%)$ which represent very positive meanings to Chinese speakers.

(5) Brand names need to be written in frequently used Chinese characters, preferably those from the list of the 3,500 most frequently used Chinese characters. Thus, the brand name can be easily read and its content easily understood. 


\section{ADAPTATION OF FOREIGN BRAND NAMES INTO THE CHINESE NAMING SYSTEM}

Brand names have a profound impact on consumer perception. This holds true across geographies and cultures. Foreign marketers not only must decide whether to adapt their international brand names, but they also must consider the form, content, style, and image such translation requires for particular markets and products. When a brand enters a foreign market, the company should treat the name adaptation process seriously and carefully, and when entering Chinesespeaking countries, such as Taiwan or the PRC, they should anticipate even more subtleties.

In adaptations from alphabetic languages to character-based languages such as Modern Standard Chinese, two general methods of brand names adaptation are available (Hong, Pecotich, Shultz, 2002, p. 29):

(1) direct translation for the meaning of the brand name, resulting in a different-sounding but same-meaning name in the local language;

(2) phonetic translation for the pronunciation of the brand name, resulting in the same or similar sound but perhaps different meaning in the local language.

With regard to foreign brands in Taiwan or the PRC markets, there are five main strategic options for adaptation (Hong, Pecotich, Shultz, 2002, p. 30):

(1) Entering the market with the original Western brand name. This strategy may provide a strong image of an imported product, taking advantage of the Western "halo" effect.

(2) Entering the market with a phonetically translated brand name. The pronunciation of the original brand name is retained while local connotations are attained.

(3) Entering the market with a directly translated brand name. Direct translation is the option of choice if the original brand name has a certain specific meaning attached.

(4) Entering the market with a combination of the original brand name and the phonetically translated name. This enables localization while retaining the image of the original.

(5) Entering the market with a combination of the original brand name and the directly translated name. A strong local identity is provided while the image of a Western or imported brand is maintained.

In practice (cf. Hong \& Pecotich \& Shultz, 2002, p. 43), the sole retention of the original Western brand name (e.g. M\&M) and the direct (literal) translation of foreign brand names (the adaptation of meaning), e.g. Apple as 蘋果 (pínguŏ 'apple') do not appear very often, because even if the brand is a globally 
well-known one or the brand name has a certain specific meaning to be translated into Chinese, their adaptations usually do not create any greater resonance with Chinese consumers. The phonetic translation is usually considered to be the best single option. This technique, also called "phonetic loan", is particularly recommended if the brand is strong on a global level. A Chinese name with a similar sound to the original one leads consumers to remember the brand. The safest line for the adoption of foreign brands seems to provide both the original brand name and the translated brand name of the product. The manipulation of brand name familiarity revealed that in the case of the well-known brand name, the best alternatives involve the retention of the original name, and the variation associated with the phonetic translations.

It can be noticed that one more strategy is possible, i.e. the creation of a completely new brand name exclusively for Chinese consumers. The new brand name does not have any sound and meaning similarities to the original. This strategy is employed very rarely, and as one of the most often given examples of the use of this method is considered Heineken, adapted as 喜 力 (xìli 'happiness and power'). However, this Chinese name for Heineken is common mainly in the PRC, in Taiwan the most popular name is 海尼根 Hăinígenn, being the phonetically translated brand name. Generally, new names are usually based upon the brand logo or connected to the characteristics of the products. The strategy of creating a new name is quite interesting for those companies that want to achieve a market position different from that of their country of origin.

It seems that the main method of the adaptation/translation of Western brand names (of the alphabetic writing) in Taiwan or the PRC can be considered a specific form of phonetic translation (cf. Kałużyńska, 2011, pp. 238-239, 241), when Chinese characters are used partly for their phonetic value (i.e. they are employed for notation of syllables/words of similar pronunciation as the Chinese syllables/ words written with the characters) and partly for their semantic value (i.e. they are employed because of the meaning of such written Chinese morphemes/words). The meaning of the adapted brand names differs from the originals, and such names usually gain positive or neutral connotations.

\section{THE RESEARCH ON LANGUAGE STRATEGIES FOR THE ADAPTATION OF WESTERN BRAND NAMES OF 50 FOOD PRODUCTS IN TAIWAN}

The research material consists of 50 Chinese adaptations of well-known foreign brand names of food products in Taiwan. The names were collected by the author in 2017, mainly as names written on the packages of the chosen food products, and later based on the list of Taiwanese food products enclosed in an unpublished Master's thesis (Tseng, 2015). As all these Chinese names were recorded 
in Chinese characters, without any information of their pronunciation, the pronunciation of them is considered the same as of words in the Modern Standard Chinese (MSC) and they are written in the Chinese phonetic alphabet (Pinyin). The author knows that because of the language diversity in Taiwan the use of the Mandarin Chinese pronunciation as one of the main standards for the categorization of Taiwanese names is far from ideal, but it seems sufficient for the purpose of this research. Some additional information on international brands and products comes from the English Wikipedia (https://en.wikipedia.org)..

It is evident that the analyzed names usually have the form of a combination of the original brand name and one of the possible strategic options of the adaptation/translation of foreign brand names into Chinese (described above). These are: a combination of phonetic translation and creation of a new meaning (CPC), a pure phonetic translation (PT), a direct (literal) translation (DT), a creation of a new name $(\mathrm{C})$, and a combination of a phonetic and direct (literal) translations (CPDT). There are also some adaptations that are not clear enough to be classified within one of these categories.

(1) A combination of phonetic translation and creation of new meaning (CPC)

\begin{tabular}{|c|c|c|c|c|}
\hline No. & Original name & Chinese name & Strategies & Notes \\
\hline 1. & Anchor & $\begin{array}{l}\text { 安佳 } \\
\bar{a} n j i \bar{a} \text { 'peaceful and } \\
\text { excellent' }\end{array}$ & $\mathrm{CPC}$ & $\begin{array}{l}\text { Dairy products, formula } \\
\text { milk } \\
\text { (New Zealand) }\end{array}$ \\
\hline 2. & Anlene & $\begin{array}{l}\text { 安怡 } \\
\text { anyí 'peaceful [and] } \\
\text { joyful' }\end{array}$ & CPC & $\begin{array}{l}\text { Dairy products, formula } \\
\text { milk } \\
\text { (New Zealand) }\end{array}$ \\
\hline 3. & Centrum & $\begin{array}{l}\text { 善存 } \\
\text { shàncún 'good being' }\end{array}$ & $\mathrm{CPC}$ & $\begin{array}{l}\text { Nutrition supplements } \\
\text { (now Great Britain, before } \\
\text { Pfizer) }\end{array}$ \\
\hline 4. & Cheetos & $\begin{array}{l}\text { 奇多 } \\
\text { qiduō 'remarkable } \\
\text { [and] numerous' }\end{array}$ & $\mathrm{CPC}$ & $\begin{array}{l}\text { Cornmeal snacks, name } \\
\text { from mascot's name, } \\
\text { Chester Cheetah (USA) }\end{array}$ \\
\hline 5. & Chips Ahoy! & $\begin{array}{l}\text { 趣多多 } \\
\text { qùduōduō 'very, } \\
\text { very interesting' }\end{array}$ & $\mathrm{CPC}$ & $\begin{array}{l}\text { Chips, snacks; name from } \\
\text { the nautical term Ships } \\
\text { Ahoy (USA) }\end{array}$ \\
\hline 6. & Combos & $\begin{array}{l}\text { 冠霣 } \\
\text { guānbăo 'crown } \\
\text { treasure' }\end{array}$ & CPC & Chips, snacks (USA) \\
\hline 7. & Doritos & $\begin{array}{l}\text { 多力多滋 } \\
\text { duōliduōzi e a lot of } \\
\text { power, a lot of taste' }\end{array}$ & $\mathrm{CPC}$ & $\begin{array}{l}\text { Chips, snacks; name from } \\
\text { Spanish doradito 'lit- } \\
\text { tle golden thing' or 'lit- } \\
\text { tle golden boy' (USA, } \\
\text { PepsiCo, Frito-Lay) }\end{array}$ \\
\hline
\end{tabular}




\begin{tabular}{|c|c|c|c|c|}
\hline 8. & Eclipse & $\begin{array}{l}\text { 易口舒 } \\
\text { yiköushù 'amiable } \\
\text { [and] comfortable } \\
\text { for mouth' }\end{array}$ & $\mathrm{CPC}$ & $\begin{array}{l}\text { Chewing gum, mint can- } \\
\text { dies (USA, Wrigley } \\
\text { Company) }\end{array}$ \\
\hline 9. & Gerber & $\begin{array}{l}\text { 嘉霣 } \\
\text { jiāăbăo 'fine treasure', } \\
\text { 'fine [and] precious' }\end{array}$ & $\mathrm{CPC}$ & $\begin{array}{l}\text { Baby food, formula milk } \\
\text { name from the owner's } \\
\text { last name (USA, Nestle) }\end{array}$ \\
\hline 10. & Hershey's & $\begin{array}{l}\text { 好時 } \\
\text { hăoshi 'good time' }\end{array}$ & $\mathrm{CPC}$ & $\begin{array}{l}\text { Chocolates name from } \\
\text { the founder's last name } \\
\text { (USA) }\end{array}$ \\
\hline 11. & Knorr & $\begin{array}{l}\text { 康璸 } \\
\text { kāngbăo 'healthy } \\
\text { [and] precious' }\end{array}$ & $\mathrm{CPC}$ & $\begin{array}{l}\text { Food and beverage name } \\
\text { from the founder's last } \\
\text { name (Germany) }\end{array}$ \\
\hline 12 . & Lay's & $\begin{array}{l}\text { 乐事 } \\
\text { lèshi 'happy event' }\end{array}$ & $\mathrm{CPC}$ & $\begin{array}{l}\text { Potato chips name from } \\
\text { a salesman's last name, } \\
\text { Herman Lay (USA) }\end{array}$ \\
\hline 13. & Nutella & $\begin{array}{l}\text { 能多益 } \\
\text { něngduoyyi 'be able } \\
\text { to much profit' }\end{array}$ & $\mathrm{CPC}$ & $\begin{array}{l}\text { Hazelnut cocoa spread } \\
\text { (Ferrero Nutella, Italy) }\end{array}$ \\
\hline 14. & Ocean Spray & $\begin{array}{l}\text { 優鮮沛 } \\
\text { yōuxiānpèi 'excel- } \\
\text { lent, fresh, abundant' }\end{array}$ & $\mathrm{CPC}$ & $\begin{array}{l}\text { Cranberry and grapefruit } \\
\text { juices, fruit snacks (USA) }\end{array}$ \\
\hline
\end{tabular}

(2) A pure phonetic translation (PT)

\begin{tabular}{|c|c|c|c|c|}
\hline No. & Original name & Chinese name & Strategies & Notes \\
\hline 1. & Lipton & $\begin{array}{l}\text { 立顿 } \\
\text { lìdùn 'establish'+ } \\
\text { 'arrange' }\end{array}$ & PT & $\begin{array}{l}\text { Tea, name from the found- } \\
\text { er's name, Thomas Lipton } \\
\text { (GB) }\end{array}$ \\
\hline 2. & Maltesers & $\begin{array}{l}\text { 麥提莎 } \\
\text { màitíshā 'barley' + } \\
\text { 'to raise' + 'kind of } \\
\text { grass' }\end{array}$ & $\mathrm{PT}$ & $\begin{array}{l}\text { Chocolate balls of malted } \\
\text { milk and barley } \\
\text { (GB, Mars) }\end{array}$ \\
\hline 3. & Maxwell House & $\begin{array}{l}\text { 麥斯威爾 } \\
\text { màisīweierer 'barley' } \\
+ \text { +'that' + 'mighty' } \\
+ \text { +'that' }\end{array}$ & PT & $\begin{array}{l}\text { Coffee name from the first } \\
\text { major customer "Maxwell } \\
\text { Hotel" in Nashville (USA) }\end{array}$ \\
\hline 4. & Mentos & $\begin{array}{l}\text { 曼陀珠 } \\
\text { màntuózhū' 'graceful' } \\
+ \text { +'hill'+ 'pearl' }\end{array}$ & PT & $\begin{array}{l}\text { Scotch mints (Perfetti Van } \\
\text { Melle) }\end{array}$ \\
\hline 5. & Milo & $\begin{array}{l}\text { 美禄 } \\
\text { méilù 'beautiful' + } \\
\text { 'salary' }\end{array}$ & PT & $\begin{array}{l}\text { Chocolate malt beverage, } \\
\text { name from the ancient } \\
\text { athlete's name Milo of } \\
\text { Croton (Australia, Nestlé) }\end{array}$ \\
\hline
\end{tabular}




\begin{tabular}{|c|c|c|c|c|}
\hline 6. & OREO & $\begin{array}{l}\text { 奥利奥 } \\
\text { àolì̀ 'ào 'profound' + } \\
\text { 'advantage' + 'pro- } \\
\text { found' }\end{array}$ & PT & $\begin{array}{l}\text { Cookies many hypothe- } \\
\text { ses, including derivations } \\
\text { from the French or 'gold' } \\
\text { (USA) }\end{array}$ \\
\hline 7. & Ovaltine & $\begin{array}{l}\text { 阿華田 } \\
\text { áhuátiān 'prefix'+ } \\
\text { 'flower' + 'field' }\end{array}$ & PT & $\begin{array}{l}\text { Chocolate, malt bever- } \\
\text { age name from Latin } \\
\text { ovum 'eggs', and malt } \\
\text { (Switzerland, GB) }\end{array}$ \\
\hline 8. & Pringles & $\begin{array}{l}\text { 品客 } \\
\text { p̌nkè 'product' + } \\
\text { 'guest' }\end{array}$ & PT & $\begin{array}{l}\text { Potato snacks name from } \\
\text { Mark Pringle, who filled } \\
\text { a US patent (USA) }\end{array}$ \\
\hline 9. & RITZ & $\begin{array}{l}\text { 麗滋 } \\
\text { lizi ' 'beautiful' + 'to } \\
\text { multiply' }\end{array}$ & PT & $\begin{array}{l}\text { Cookies, crackers the } \\
\text { name Ritz, appealed to } \\
\text { individuals by offering } \\
\text { them ,a bite of the good } \\
\text { life" (USA) }\end{array}$ \\
\hline 10. & Snapple & $\begin{array}{l}\text { 思樂璸 } \\
\text { sìlèbăo 'to think' + } \\
\text { 'pleasure' + 'treasure’ }\end{array}$ & PT & $\begin{array}{l}\text { Tea, juices name from } \\
\text { words snappy and apple } \\
\text { (USA) }\end{array}$ \\
\hline 11. & Sprite & $\begin{array}{l}\text { 雪碧 } \\
\text { xuěbi 'snow'+ } \\
\text { 'green jade' }\end{array}$ & PT & $\begin{array}{l}\text { Lemon soft drinks } \\
\text { (Germany, Coca-Cola) }\end{array}$ \\
\hline 12. & Sunkist & $\begin{array}{l}\text { 香吉士 } \\
\text { xiāngjíshi 'fragrant' } \\
+ \text { +'lucky'+ 'person' }\end{array}$ & PT & $\begin{array}{l}\text { Soft-drink name from } \\
\text { sun-kissed, to describe } \\
\text { California's oranges } \\
\text { (USA) }\end{array}$ \\
\hline
\end{tabular}

(3) A creation of a new brand name (C)

\begin{tabular}{|c|l|l|l|l|}
\hline No. & Original name & \multicolumn{1}{|c|}{ Chinese name } & Strategies & \multicolumn{1}{|c|}{ Notes } \\
\hline 1. & Carnation & $\begin{array}{l}\text { 三花 } \\
\text { sānhuā 'three flo- } \\
\text { wers' }\end{array}$ & C & $\begin{array}{l}\text { Evaporated milk, coffee } \\
\text { cream logo consists of } \\
\text { three carnation flowers } \\
\text { (USA, now Nestlé) }\end{array}$ \\
\hline 2. & Doublemint & $\begin{array}{l}\text { 青箭 } \\
\text { qingjiàn 'green } \\
\text { arrow/spear' }\end{array}$ & C & $\begin{array}{l}\text { Chewing gum logo con- } \\
\text { sists of a green double } \\
\text { edge arrow/spear } \\
\text { (USA, Wrigley Company) }\end{array}$ \\
\hline 3. & Juicy Fruit & $\begin{array}{l}\text { 黄箭 } \\
\text { huángjiàn 'yellow } \\
\text { arrow/spear' }\end{array}$ & C & $\begin{array}{l}\text { Chewing gum logo con- } \\
\text { sists of an elongated dou- } \\
\text { ble edge arrow/spear with } \\
\text { the yellow background } \\
\text { (USA, Wrigley Company) }\end{array}$ \\
\hline 4. & Kit Kat & $\begin{array}{l}\text { 奇巧 } \\
\text { qíqiăo 'exquisite' }\end{array}$ & C & $\begin{array}{l}\text { Chocolates name from Kit } \\
\text { Cat (18 }{ }^{\text {th }} \text { century), a food } \\
\text { name (Nestlé) }\end{array}$ \\
\hline
\end{tabular}




\begin{tabular}{|c|c|c|c|c|}
\hline 5. & Minute Maid & \begin{tabular}{|l|} 
美粒果 \\
méiliguŏ 'beautiful' \\
+ 'grain' + 'fruit', \\
'beautiful grain fruit?'
\end{tabular} & $\mathrm{C}$ & $\begin{array}{l}\text { Beverage, juices, soft } \\
\text { drinks name implying the } \\
\text { juice was quick and easy } \\
\text { to prepare (USA, Coca- } \\
\text { Cola) }\end{array}$ \\
\hline 6. & Skittles & $\begin{array}{l}\text { 彩虹糖 } \\
\text { căihóngtáng 'rain- } \\
\text { bow candy’ }\end{array}$ & $\mathrm{C}$ & $\begin{array}{l}\text { Fruit-flavored, multicol- } \\
\text { ored candy (British, USA) }\end{array}$ \\
\hline 7. & Stresstabs & $\begin{array}{l}\text { 克補 } \\
\text { kèbŭ 'be able to } \\
\text { mend/repair' }\end{array}$ & $\mathrm{C}$ & $\begin{array}{l}\text { Vitamin B-complex sup- } \\
\text { plement (Pfizer) }\end{array}$ \\
\hline 8. & Sugus & $\begin{array}{l}\text { 瑞士糖 } \\
\text { ruishitáng ‘swiss } \\
\text { candy’ }\end{array}$ & $\mathrm{C}$ & $\begin{array}{l}\text { Candy, name from the } \\
\text { Swiss chocolate company } \\
\text { Suchard }\end{array}$ \\
\hline 9. & $\begin{array}{l}\text { Wrigley's } \\
\text { Spearmint }\end{array}$ & \begin{tabular}{|l|} 
白箭 \\
báijiàn 'white arrow/ \\
spear'
\end{tabular} & $\mathrm{C}$ & $\begin{array}{l}\text { Chewing gum name from } \\
\text { a plant spearmint logo } \\
\text { consists of a green arrow/ } \\
\text { spear with Spearmint writ- } \\
\text { ten in white letters (USA) }\end{array}$ \\
\hline
\end{tabular}

(4) A direct (literal) translation (DT)

\begin{tabular}{|c|c|c|c|c|}
\hline No. & Original name & Chinese name & Strategies & Notes \\
\hline 1. & $\begin{array}{l}\text { BLUE } \\
\text { DIAMOND }\end{array}$ & $\begin{array}{l}\text { [加州]藍鑚 } \\
\text { [Jiāzhōu] lánzuān } \\
\text { '[Californian] blue } \\
\text { diamond' } \\
\end{array}$ & DT & $\begin{array}{l}\text { Nuts, almonds } \\
\text { (USA, California) }\end{array}$ \\
\hline 2. & Great Day & \begin{tabular}{|l|} 
得意的一天 \\
Déyide yìtiān 'com- \\
placent day'
\end{tabular} & DT & $\begin{array}{l}\text { Oil, instant food } \\
\text { (USA) }\end{array}$ \\
\hline 3. & Green Giant & \begin{tabular}{|l|} 
緑巨人 \\
lüjùrén 'green giant'
\end{tabular} & DT & $\begin{array}{l}\text { Corn cans name from } \\
\text { the name of the company } \\
\text { mascot, Jolly Green Giant } \\
\text { (USA, General Mills) }\end{array}$ \\
\hline 4. & Nature Valley & \begin{tabular}{|l|} 
天然谷 \\
tiānrángŭ 'nature \\
valley’
\end{tabular} & DT & $\begin{array}{l}\text { Granola bars, cereals } \\
\text { (USA) }\end{array}$ \\
\hline 5. & Smarties & $\begin{array}{l}\text { 聰明豆 } \\
\text { cóngmingdòu } \\
\text { ‘clever beans' }\end{array}$ & DT & $\begin{array}{l}\text { Chocolate confectionary } \\
\text { (UK, Nestlé) }\end{array}$ \\
\hline 6. & Swiss Miss & \begin{tabular}{|l} 
瑞士妞 \\
ruishinī̄ 'swiss girl'
\end{tabular} & DT & $\begin{array}{l}\text { Chocolates, cocoa bever- } \\
\text { age (USA) }\end{array}$ \\
\hline 7. & TREE TOP & \begin{tabular}{|l} 
樹頂 \\
shùdı̌ng 'tree top'
\end{tabular} & DT & $\begin{array}{l}\text { Apple juice "the highest } \\
\text { quality fruit grows at the } \\
\text { tops of trees" (USA) }\end{array}$ \\
\hline
\end{tabular}


(5) A combination of phonetic and direct (literal) translations (CPDT)

\begin{tabular}{|c|l|l|l|l|}
\hline No. & Original name & \multicolumn{1}{|c|}{ Chinese name } & Strategies & \multicolumn{1}{|c|}{ Notes } \\
\hline 1. & Coffee-mate & $\begin{array}{l}\text { 咖啡伴侣 } \\
k \bar{a} f \bar{e} i \text { bànlü 'coffee- } \\
\text { mate' }\end{array}$ & CPDT & $\begin{array}{l}\text { Coffee creamers } \\
\text { (USA, Nestlé) }\end{array}$ \\
\hline 2. & Eagle & $\begin{array}{l}\text { 鹰牌 } \\
\text { yìngpài } \\
\text { 'eagle brand' }\end{array}$ & CPDT & $\begin{array}{l}\text { Sweetened condensed } \\
\text { milk (USA) }\end{array}$ \\
\hline
\end{tabular}

(6) Unclear categories

\begin{tabular}{|c|c|c|c|c|}
\hline No. & Original name & Chinese name & Strategies & Notes \\
\hline 1. & Dove & $\begin{array}{l}\text { 德芙 } \\
\text { défù 'morality'+ } \\
\text { 'bound morfem/lotus'; } \\
\text { 'moral lotus?' }\end{array}$ & $\mathrm{PT} / \mathrm{CPC}$ & $\begin{array}{l}\text { Chocolate } \\
\text { (USA, Mars) }\end{array}$ \\
\hline 2. & Extra & $\begin{array}{l}\text { 益齒達 } \\
\text { yichídá 'profit' + } \\
\text { 'tooth' + 'to reach'; } \\
\text { 'profit reached by } \\
\text { teeth?' }\end{array}$ & $\mathrm{PT} / \mathrm{CPC}$ & $\begin{array}{l}\text { Chewing gum (USA, } \\
\text { Wrigley Company) }\end{array}$ \\
\hline 3. & Fanta & $\begin{array}{l}\text { 芬達 } \\
\text { fēndá 'fragrance' + } \\
\text { 'reach'; 'fragrance } \\
\text { reaches?' }\end{array}$ & $\mathrm{PT} / \mathrm{CPC}$ & $\begin{array}{l}\text { fruit-flavored carbonated } \\
\text { soft drinks, name from } \\
\text { Fantasie in German } \\
\text { (Coca-Cola Company) }\end{array}$ \\
\hline 4. & Klim & $\begin{array}{l}\text { 克寧 } \\
\text { kèníng 'to be able to' } \\
\text { + 'peaceful'; 'can be } \\
\text { peaceful?' }\end{array}$ & $\mathrm{PT} / \mathrm{CPC}$ & $\begin{array}{l}\text { Formula milk name from } \\
\text { reversed milk, the slo- } \\
\text { gan "Spell it backwards" } \\
\text { (USA) }\end{array}$ \\
\hline 5. & Snickers & $\begin{array}{l}\text { 士力架 } \\
\text { shilijià 'person' + } \\
\text { 'power' + 'bar'; 'per- } \\
\text { son power bar?' }\end{array}$ & $\mathrm{PT} / \mathrm{CPC}$ & $\begin{array}{l}\text { Chocolate bars name } \\
\text { from the Swedish word } \\
\text { snickare 'carpenter' }\end{array}$ \\
\hline 6. & SUNSWEET & $\begin{array}{l}\text { 太陽牌 } \\
\text { tàiyàngpài 'sun brand' }\end{array}$ & $\mathrm{C} / \mathrm{DT}$ & $\begin{array}{l}\text { Dried fruit, raisins, } \\
\text { prunes (USA) }\end{array}$ \\
\hline
\end{tabular}

\section{CONCLUSIONS}

The paper has discussed some language strategies in the domain of the adaptation of foreign brand names (trade names) in the context of Chinese language, society and culture. The research on language strategies for the adaptation/translation of 
Western brand names of 50 food products in Taiwan shows some characteristics of these strategies and the resulted adapted names, namely:

(1) Various strategies for the adaptation of brands have been used. These are: a combination of phonetic translation and creation of a new meaning (CPC) 14 brands (28\%), a pure phonetic translation (PT) -12 brands (24\%), a creation of a new name (C) -9 brands (18\%), a direct (literal) translation (DT) 7 brands (14\%), and a combination of a phonetic and direct (literal) translations (CPDT) -2 brands ( $4 \%$ ). There are also some adaptations ( 6 brands, $12 \%$ ) that are not clear enough to be classified within one of these categories. It cannot be stated on the basis of this research, however, it seems that the main method of adaptation/translation of Western brand names (of the alphabetic writing) in Taiwan or China can be considered a retention of the original names together with a specific form of their phonetic translation into Chinese, when Chinese characters are used partly for their phonetic value and partly for their semantic value. Thus, the adapted brand names can retain their original brand names and obtain both phonetic similarities and new evocative associations.

(2) Most of the analyzed adaptations of foreign names are rather short: $50 \%$ of them are in two syllables, $40 \%$ are in three syllables. $8 \%$ are of four syllables, and $2 \%$ (one name) is in five syllables. There are no examples of one-syllabled brands.

(3) Tone structures in two-syllables are: H-L (9 cases), L-L ( 7 cases), H-H (5 cases), L-H (4 cases). The preferable tone structures in three-syllables are: H-H-L (4 cases), L-H-H (4 cases), L-L-H (4 cases), and L-L-L (4 cases). It seems, on the basis of this research, that sonority has not been considered a very important factor for adaptations of these foreign brand names.

(4) Semantically, the Chinese names of foreign brands are evidently positive, with good or neutral meaning.

(5) Chinese names of foreign brands have been written in the most frequently used Chinese characters, so they can be easily read and understood.

\section{REFERENCES}

Chan, A.K.K., \& Huang, Y. (1997). Brand naming in China: a linguistic approach. Marketing Intelligence and Planning, 15(5), 227-234.

Chan, A.K.K., \& Huang, Y. (2001). Chinese brand naming: A linguistic analysis of the brands of ten product categories. Journal of Product \& Brand Management, 10(2), 103-119. https://doi. org/10.1108/10610420110388663

Chao, Y.R. (1968). A Grammar of Spoken Chinese. Berkeley: University of California Press.

F an, Y. (2002). The national image of global brands. Journal of Brand Management, 9(3), 180-192. 
Hong, F.C., Pecotich, A., \& Schultz, C.J. (2002). Brand name translation: Language constraints, product attributes, and consumer perceptions in East and Southeast Asia. Journal of International Marketing, 10(2), 29-45.

Jin, M. 金,鸣 (2002). Chenggong qiming shiyong zhinan 成功起名使用指南 [A Guide to Successful Naming]. Beijing: Nongcun Dongwu Chubanshe.

Kałużyńska, I. (2002). Contemporary Chinese Place Names. Names of Administrative Divisions at County and City Level. Bern: Peter Lang AG.

Kałużyńska, I. (2008). Chinese Female Namings. Past and Present. Warszawa: AGADE.

Kałużyńska, I. (2011). Z zagadnień chrematonimii chińskiej [On Chinese chrematonymy]. In M. Biolik \& J. Duma (Eds.), Chrematonimia jako fenomen wspótczesności [Chrematonymy as a Phenomenon of Modern Time] (pp. 235-242). Olsztyn: Wydawnictwo UWM.

Luo, X. 骆, 贤凤. (2001). Zhongyingwen shangbiao fanyi guankui 中英文商标翻译管窥 [ChineseEnglish translation of brands]. Shandong Shida Waiguoyu Xueyuan Xuebao, 4, 67-69.

Tseng, H. 曾, 惠美. (2015). Pinpai ji gongsi mingcheng fanyi zhi celüe fenxi 品牌及公司名称翻译之 策略分析：多样等效及文本功能之䏌系性. A Strategic Analysis of the Translations of Brands and Company Names: Relevance to varied equivalences and textual functions. Unpublished master's thesis. National Kaohsiung First University of Science and Technology, Taiwan, R.O.C.

\section{SUMMARY}

\section{LANGUAGE STRATEGIES FOR THE ADAPTATION OF WESTERN BRAND NAMES IN TAIWAN}

The paper deals with some language strategies in the domain of the adaptation of foreign brand names (trade names) in Taiwan (ROC) in the context of Chinese language, society and culture. It also presents the results of the author's investigation into 50 Chinese/Taiwanese adaptations of brands of foreign food products. In the Chinese naming culture, proper names are predominantly semantically transparent and most members of Chinese society still believe that names can influence the fate of the objects named. It is evident, that brand names play a crucial role in the marketing of products and in their acceptance by the consumers, and ultimately their purchase decisions. Good and pleasing brand names contribute to the success of products, while improper and ugly names may contribute to their failure. In a time of globalization, many foreign products and brand names occur in Chinese-speaking countries, such as the PRC and Taiwan, probably the largest consumer markets in international business. Consumers' behavior and language are usually among the major barriers to the international market, so it is important to know the linguistic and social content of Chinese names and typical language strategies for the adaptation of Western brand names. 